
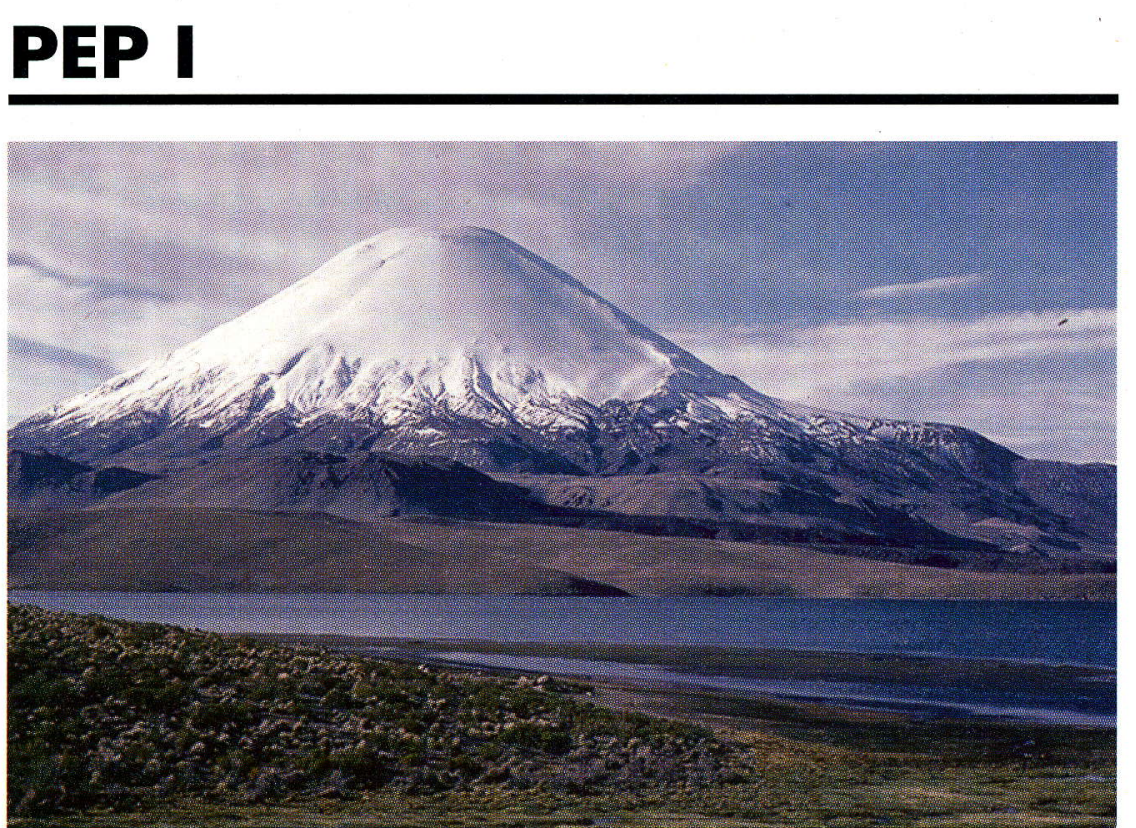

Volcanos, ice cores, lake sediments, peat bogs and treerings: Volcano Parinacota and Laguna Chungara in the Chilean Altiplano are illustrating the variety of paleo-archives available within the PEP I Transect. (Foto: M. Grosjean, Dept. of Geography, University of Bern, Switzerland).

\section{COORDINATION NEWS}

- The plan to convene the first "Interhemispheric Paleoclimates of the Americas" meeting is taking shape.

The meeting will be held in Merida, Venezuela, March 1998.

The following topics, to be organized by coordinators, will be discussed:

- Modern Climate Variability, - El Niño/Southern Oscillation, - Last 2000 Years Climate Variability, - Mid Holocene Climate Optimum/ Neoglacial,

- Late-Glacial Climate Variability, - Last Glacial Maximum.

Coordinators of each topic session will provide a state-of-the-art interhemispheric synopsis, which is followed by specific comparative presentations from the marine and terrestrial realm, addressing interhemispheric linkages.

Presentations will be published subsequently in a book.
- The Spanish translation of the revised and updated PAGES-

PANASH and PEP I portion of the PAGES Series 95-1 is now available

from the coordinator, Vera Markgraf, upon request (PAGES Series 96- 6). Copies were distributed at the II Southern Connection Meeting in Valdivia, January 6 through 11, 1997. This version also includes the revised and updated site inventory of the Latin American Pollen Database, previously published as a Paleoclimatology Publication Series Report No. 4, 1996, (V. Markgraf, L. Anderson, J. Keltner, E. Grimm "The Latin American Pollen Database Site Inventory", World Data Center-A for Paleoclimatology, NOAA Paleoclimatology Program, Boulder, Colorado, 80303). This inventory, which is also available on the WWWeb (http://www.ngdc.noaa.gov/paleo/ paleo/html) lists all reported sites of pollen records in Latin America, including geographic information, radiocarbon chronology, age of record, and publication.

PEP I Research and Workshop Activities

PEP II Activities in New Zealand, China and Taiwan

Workshop Reports

Inside PAGES

National Activities around the World

PAGES Calendar

PAGES Scientific Highlight:

Great Barrier Reef 'Climatic Optimum' at 5,800 Y BP (M. K. Gagan et al.)

EDITORIAL

$T_{\text {his is the first of the new- }}$

style PAGES Newsletters. It

reflects our need to respond to the change in the orientation of PAGES from activities concerned mainly with Agenda-setting, towards an increasing emphasis on the implementation of PAGES research.

In the present Newsletter, we have emphasized in different ways, the activities going on within two of the three PEP (Pole-Equator-Pole) Transects. We have also introduced two examples of developments in PAGES research coordinated at national level, in the hope that this will encourage other national groups and research consortia to submit material for inclusion in future issues.

We plan to circulate three issues of the Newsletter per year, as before and we also plan to retain the main components of previous Newsletters - Workshop Reports, the illustrated, scientific 'PAGES Highlight', short discussion articles, personal news of the PAGES community and the Calendar. The success of all these depends on input from readers as much as on the efforts of the Project Office and editorial staff.

The next newsletter should contain details of developments in PEP III, as well as a major section devoted to the impressive early successes of the IMAGES programme. We shall emphasize short, wellillustrated summaries of 'highlights' wherever possible. The aim is to introduce the strength and flavour of the science in the best and briefest way possible, not to turn the Newsletter into a vehicle for 'grey' publications. 